\title{
Observation of Pyramidal Lobe and Levator Glandulae Thyroideae and Their Macroscopic Feature and Relation with Whole Thyroid Gland: A Postmortem Study.
}

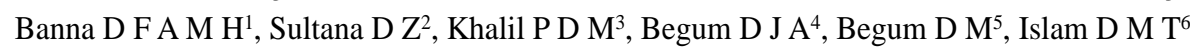

\begin{abstract}
:
Back Ground: The thyroid is a brownish red, highly vascular earliest endocrine glandular structure appears in mammal. The size of thyroid gland varies considerably with age, sex, physiologic state, race and geographical location. It is larger and heavier in mature females than in males, and it hypertrophies during menstruation and pregnancy. Diseases of thyroid may need surgical intervention. During thyroid surgery, there is every possibility of occurrence of haemorrhage and recurrent laryngeal nerve injury. So this study is to carry out the macroscopic and microscopic architecture of thyroid gland of different age and sex groups in Bangladeshi people to establish a normal standard. This study will also help in minimizing complications of thyroid surgery and tracheostomy.
\end{abstract}

Study design: Mainly descriptive cross-sectional study with an analytic component.

Place and period of study: Department of Anatomy, Sylhet M. A. G. Osmani Medical College, Sylhet, from 1st July 2006 to 30th June 2007.

Materials: The study was carried out on 54 autopsied human thyroid glands aged 5 to 65 years. Thyroid glands were collected from unclaimed dead bodies autopsied in morgue of Sylhet M. A. G. Osmani Medical College, Sylhet.

Methods: The collected specimens were divided into age group A (10 years and below), group B (11 to 20 years), group $C$ (21 to 30 years), group $D$ (31 to 40 years), group $E$ (41 to 50 years) and group $F$ (5lyears and above). All specimens were examined morphologically by fine dissection method.

Result: Pyramidal lobe and levator glandulae thyroideae

1. Dr. Fakhrul Amin Mohammad Hasanul Banna, Assistant Professor and Head of Anatomy, Kumudini Women's Medical College, Tangail

2. Dr. Zakia Sultana, Professor and Head of Anatomy, Sylhet MAG Osmani Medical College, Sylhet

3. Prof. Dr. Mansur Khalil, Professor and Head of Anatomy, Chittagong Medical College, Chittagong

4. Dr. Jahan Ara Begum, Associate Professor of Anatomy, Bangabandhu Sheikh Mujib Medical University (BSMMU), Dhaka

5. Dr. Manowara Begum, Associate Professor of Anatomy, Dhaka Medical College, Dhaka

6. Dr. Mohammod Towhidul Islam, Associate Professor, Department of Pharmacology, Kumudini Women's Medical College, Tangail. were present in $37.04 \%$ and $59.26 \%$ cases respectively and were situated to the left side of midline in most of the cases. In most of the cases levator glandulae thyroideae had association with apex of pyramidal lobe to the body of the hyoid bone.

Conclusion: From observation and results it reached conclusion that the present study will help to increase the information pool on the anatomy of thyroid gland of Bangladeshi people. To establish a normal standard for Bangladeshi people, further studies with large samples from different zones including goitre endemic zones of the country are suggested.

Keywords: Observation, pyramidal lobe, levator glandulae thyroideae, macroscopic relation, thyroid gland, postmortem.

\section{Introduction:}

The thyroid gland is the largest endocrine gland in the body, and is unpaired1. It is a horseshoe-shaped mass clasping the upper part of the trachea ${ }^{2}$. The thyroid gland consists of two symmetrical lobes united by an isthmus, lies in front of the second, third and fourth tracheal ring 3,4 . A pyramidal lobe, of frequent occurrence but variable size, extends upward from the isthmus or from the junction of the isthmus and one of the lateral lobes, usually the left ${ }^{5}$ and connected to the thyroid cartilage and hyoid bone6. There may be in addition to the pyramidal lobe, a fibromuscular band known as the levator glandulae thyroideaewhich usually replace the upper part of the pyramidal lobe ${ }^{7}$.

The size of thyroid gland varies considerably with age, sex, physiologic state, race and geographical location. It is larger and heavier in mature females than in males, and it hypertrophies during menstruation and pregnancy ${ }^{8}$. Any abnormal enlargement of the thyroid gland is called goitre. Major enlargements may be associated with either excessive or deficient production of thyroid hormones ${ }^{9}$.

The common diseases of thyroid gland are hypothyroidism (cretinism in children and myxedema in adult), hyperthyroidism, autoimmune thyroiditis, Graves' disease. Among these, hypothyroidism due to iodine deficiency is commonest. $5 \%$ of the populations are affected from various thyroid disorders. Over $90 \%$ patients with hyperthyroidism are due to Graves's disease, multinodular goitre and 
autonomously functioning thyroid nodule (toxic adenoma). During thyroid surgery, there is every possibility of occurrence of haemorrhage and recurrent laryngeal nerve injury.

The thyroid is the earliest of the pharyngeal derivatives to make its appearance ${ }^{10}$. It begins to develop by about 24day (in week 4) after fertilization from a median endodermal thickening in the floor of the primitive pharyn $x^{11,12}$ between the tuberculum impar and the copula at a point later indicated by the foramen cecum ${ }^{13}$. As the embryo elongates and undergoes differential growth, the thyroid diverticulum migrates anteriorly and inferiorly to the hyoid bone and laryngeal cartilages tethered by a slender thyroglossal duct $^{14}$. Almost from its initial appearance this thyroid primordium (thyroglossal duct) is bilobed ${ }^{10}$. Subsequently the thyroid descends in front of the pharyngeal gut as a bilobed diverticulum ${ }^{13}$. At first the thyroid diverticulum is hollow but it soon becomes solid and divides into right and left lobes, which are connected by the isthmus of the thyroid gland. By seventh weeks the thyroid gland has assumed its definitive shape and has usually reached its final site in the neck. By this time the thyroglossal duct has normally degenerated and disappeared ${ }^{12}$.

A pyramidal lobe, extending from the isthmus, is seen in about $50 \%$ of thyroid glands and is derived from the thyroglossal duct ${ }^{11}$. The pyramidal lobe may be attached to the hyoid bone by fibrous and / or some smooth muscle the levator glandulae thyroideae, which represent a persistent part of thyroglossal duct ${ }^{12}$.

\section{Materials:}

This study was done on fifty-four (54) human thyroid glands of all ages and both sexes. These entire samples were collected from unclaimed autopsied bodies in the morgue of the department of Forensic Medicine of Sylhet M.A.G. Osmani Medical College after requisite legal formalities. As autopsy is not performed routinely in our country for natural deaths, the samples were collected from medicolegal cases within twenty-four (24) hours after death before appearance of signs of putrefaction. The human thyroid gland with related structures was collected as enmass from November 2006 to April 2007.

The collected samples were washed gently with tap water. Blood and blood clots were removed. Each sample was tagged with a piece of waxed cloth which bear an identification number along with the age and sex of the victim. Then the sample was fixed and preserved in $10 \%$ formol saline solution.

\section{Methods:}

\section{Place and duration of study:}

This study was carried out in the Department of Anatomy, Sylhet M.A.G. Osmani Medical College (SOMC) from July 2006 to June 2007. Age and sex of cadaver were collected from Department of Forensic Medicine, SOMC, recorded in the register book against respective number of the sample.

\section{Grouping of the samples:}

Grouping of the samples was done according to age into 6 groups (Table- I) and according to sex into 2 groups (Male, $\mathrm{n}=43$ \& Female, $\mathrm{n}=11$ ).

Table - I. Age distribution in different age groups of present study.

\begin{tabular}{|l|l|c|c|}
\hline Age range (years) & Group & $\begin{array}{c}\text { Number of Cadavers/ } \\
\text { Thyroid glands }\end{array}$ & Percentage \\
\hline 10 years and below & A & $\begin{array}{c}6 \\
\text { (Male 5 \& female 1) }\end{array}$ & 11.11 \\
\hline 11 years to 20 years & B & $\begin{array}{c}8 \\
\text { (Male 6 \& female 2) }\end{array}$ & 14.81 \\
\hline 21 years to 30 years & C & $\begin{array}{c}14 \\
\text { (Male 12 \& female 2) }\end{array}$ & 25.93 \\
\hline 31 years to 40 years & D & $\begin{array}{c}11 \\
\text { (Male 9 \& female 2) }\end{array}$ & 20.37 \\
\hline 41 years to 50 years & E & $\begin{array}{c}9 \\
\text { (Male 8 \& female 1) }\end{array}$ & 16.67 \\
\hline 51 years and above & F & $\begin{array}{c}6 \\
\text { (Male 3 \& female 3) }\end{array}$ & 11.11 \\
\hline
\end{tabular}

\section{The parameters studied:}

1.Observation (presence/ absence) of pyramidal lobe.

2. Observation (presence/ absence) of levator glandulae thyroideae and its relation with the pyramidal lobe.

\section{Observation and measurement procedure of pyramidal lobe and levator glandulae thyroideae:}

The anterior aspect of the sample block consisting of tongue, pharynx, oesophagus, larynx, trachea, thyroid and parathyroid glands, major vessels of the neck etc. were dissected and the topographical relations of the thyroid glands were observed. During dissection, observation notes were kept about the existence of the pyramidal lobe. If present, its position was noted and its length from base to apex, the breadth at the base and thickness was measured in $\mathrm{cm}$.

Levator glandulae thyroideae muscle was searched. When present, its craniocaudal extension was noted and the relation with pyramidal lobe was also observed.

\section{Observation And Results:}

\section{Pyramidal lobe (table - II, Fig. 1 \& 3)}

It was found that $20(37.04 \%)$ out of 54 thyroid gland has pyramidal lobe. The incidence was being $16(37.21 \%)$ in male and $4(36.36 \%)$ in female. In each case the pyramidal lobe was single. It was also found from observations that 
this lobe was situated more on the left side then on the right. Its base was mostly attached to the left half of upper border of the isthmus with or without encroachment on the adjacent part of the left lobe. In 3 samples its base was attached directly to the left lode and in 2 samples to the right lobe. In one sample its apex has no association with levator glandulae thyroideae. The length (base to apex) and the breadth and anteroposterior thickness at the base of this lobe varied from 0.4 to $3.7 \mathrm{~cm}, 0.6$ to $1.6 \mathrm{~cm}$ and 0.2 to 0.6 $\mathrm{cm}$ respectively. The mean length, breadth and anteroposterior thickness of this lobe were $1.87 \pm 1.04,1.13$ \pm 0.33 and $0.43 \pm 0.12 \mathrm{~cm}$ respectively.

\section{Levator glandulae thyroideae (table -III, Fig. 2 \& 3)}

In this study, out of 54 sample levator glandulae thyroideae (LGT) was found in $32(59.26 \%)$ samples of which 27 $(62.79 \%)$ male and $5(45.45 \%)$ female. In the male 15 samples of it, the lower end was associated the apex of pyramidal and 12 samples had no association with the lobe. In the female 4 samples of it, the lower end was associated the apex of pyramidal and 1 sample had no association with the pyramidal lobe. In samples where the pyramidal lobe was absent, the lower attachment was with isthmus of thyroid gland in 9 cases, both right and left lobe in 2 cases and left lobe in 3 case. In 4 (12.5\%) samples upper end attached to the thyroid cartilage and the others to the body of hyoid bone. In 3 samples both lobes of thyroid gland were separated i.e. isthmus was absent and in 2 cases the lower end of levator glandulae thyroideae was bifurcated and attached to each lobe of the thyroid gland. In one sample there was 2 levator glandulae thyroideae. The length of levator glandulae thyroideae varied from 0.4 to $5.4 \mathrm{~cm}$. Mean length of levator glandulae thyroideae was $2.48 \pm$ $1.15 \mathrm{~cm}$.

\section{Discussion:}

The incidence of pyramidal lobe mentioned in the textbooks varied widely. Dozois (1977), Moore and Dalley (1999), Hansen (1997), Pansky (1982), described pyramidal lobe present in about 50\% cases 11,14,15,16. Marshall (1895) observed and April (1997) described a pyramidal lobe occasionally $(43 \%)$ found extends superiorly from the middle of the isthmus which is a remnant of thyroglossal duct 17, 18. Hamilton (1976) described pyramidal lobe present in about $40 \%$ individual and arises more commonly from left of the midline ${ }^{19}$. Present study confirmed it. DeGroot (2001) described pyramidal lobe present in about $15 \%$ population which was lower than present study ${ }^{20}$.

Harjeet et al. (2004) found pyramidal lobe in $28.9 \%$ of specimen and Izenstark et al. (1969) found in 35\% cases, which was below present study21, 22. Enayetullah (1996) found pyramidal lobe in $25(50 \%)$ cases and single in every case, which was above present study ${ }^{23}$. The incidence was being equal in male and female. He also observed that this lobe was situated more on the left than on the right. Begum (2004) observed pyramidal lobe in $26.7 \%$ cases, which was below present study 24 . She also observed this lobe was situated more on the left than right.

Harjeet et al. (2004) found LGT in $19.5 \%$ thyroid glands. In glands with LGT, it extended caudally from the body of the hyoid bone in $53.2 \%$ specimens $^{21}$. In $10.8 \%$ instances, it arose from the median thyrohyoid ligament. Lehr (1979) found LGT in one case only $(0.49 \%)^{25}$. Enayetullah (1996) studied and found LGT in $32 \%$ cases and its association with pyramidal lobe in $22 \%$ cases $^{23}$. In most cases LGT were associated with pyramidal lobe and most of the pyramidal lobes were situated on the left side. Begum (2004) found LGT in $15 \%$ cases and all of them extended from apex of the pyramidal lobe to the body of the hyoid bone $^{24}$. The incidence of LGT in present study was higher than studies of above mentioned authors. But the association with pyramidal lobe and attachment to hyoid bone was nearly similar.

Table - II. Incidence of pyramidal lobe with its origin and its relation to isthmus.

\begin{tabular}{|c|c|c|c|c|c|c|c|c|}
\hline \multirow{2}{*}{ Group } & \multirow[b]{2}{*}{ Sex } & \multirow{2}{*}{$\begin{array}{l}\text { Number of } \\
\text { specimen } \\
\text { (n) }\end{array}$} & \multicolumn{5}{|c|}{ Attachment of pyramidal lobe with } & \multirow{2}{*}{$\begin{array}{l}\text { Total } \\
\text { number of } \\
\text { thyroid } \\
\text { with } \\
\text { pyramidal } \\
\text { lobe }\end{array}$} \\
\hline & & & $\begin{array}{l}\text { Left } \\
\text { side of } \\
\text { isthmus }\end{array}$ & $\begin{array}{l}\text { Middle } \\
\text { of } \\
\text { isthmus }\end{array}$ & $\begin{array}{l}\text { Right } \\
\text { side of } \\
\text { isthmus }\end{array}$ & $\begin{array}{l}\text { Left } \\
\text { lobe }\end{array}$ & $\begin{array}{l}\text { Right } \\
\text { lobe }\end{array}$ & \\
\hline \multirow[t]{2}{*}{ A } & Male & 5 & 0 & 0 & 0 & 1 & 1 & 2 \\
\hline & Female & 1 & 0 & 0 & 0 & 0 & 0 & \\
\hline \multirow[t]{2}{*}{ B } & Male & 6 & 1 & 0 & 1 & 0 & 0 & 3 \\
\hline & Female & 2 & 0 & 1 & 0 & 0 & 0 & \\
\hline \multirow[t]{2}{*}{$\mathrm{C}$} & Male & 12 & 0 & 2 & 1 & 2 & 0 & 5 \\
\hline & Female & 2 & 0 & 0 & 0 & 0 & 0 & \\
\hline \multirow[t]{2}{*}{$\mathrm{D}$} & Male & 9 & 3 & 1 & 0 & 0 & 0 & 5 \\
\hline & Female & 2 & 1 & 0 & 0 & 0 & 0 & \\
\hline \multirow[t]{2}{*}{$\mathrm{E}$} & Male & 8 & 0 & 1 & 0 & 0 & 11 & 3 \\
\hline & Female & 1 & 1 & 0 & 0 & 0 & 0 & \\
\hline \multirow[t]{2}{*}{$\mathrm{F}$} & Male & 3 & 1 & 0 & 0 & 0 & 0 & 2 \\
\hline & Female & 3 & 0 & 0 & 1 & 0 & 0 & \\
\hline $\begin{array}{l}\text { Total } \\
(\%)\end{array}$ & & $\begin{array}{l}54 \\
(100 \%) \\
\end{array}$ & $7(35 \%)$ & $5(25 \%)$ & $3(15 \%)$ & \begin{tabular}{|l|}
3 \\
$(15 \%)$ \\
\end{tabular} & \begin{tabular}{|c|}
2 \\
$(10 \%)$ \\
\end{tabular} & $\begin{array}{l}20 \\
(37.04 \%) \\
\end{array}$ \\
\hline
\end{tabular}

Table - III. Incidence of levator glandulae thyroideae and its association with pyramidal lobe.

\begin{tabular}{|l|l|l|l|l|l|l|l|}
\hline Group & Sex & $\begin{array}{l}\text { Number of } \\
\text { specimen } \\
\text { n) }\end{array}$ & $\begin{array}{l}\text { Preence of } \\
\text { levator } \\
\text { glandulae } \\
\text { thyroideae }\end{array}$ & $\begin{array}{l}\text { Association } \\
\text { with } \\
\text { pyramidal } \\
\text { lobe }\end{array}$ & $\begin{array}{l}\text { Left side } \\
\text { of } \\
\text { isthmus }\end{array}$ & $\begin{array}{l}\text { Right } \\
\text { side of } \\
\text { isthmus }\end{array}$ & $\begin{array}{l}\text { Middle of } \\
\text { isthmus }\end{array}$ \\
\hline A & Male & 5 & 5 & 2 & 1 & 0 & 2 \\
\hline & Female & 1 & 1 & 0 & 0 & 0 & 1 \\
\hline B & Male & 6 & 2 & 1 & 0 & 0 & 0 \\
\hline & Female & 2 & 1 & 1 & 0 & 0 & 0 \\
\hline C & Male & 12 & 8 & 5 & 0 & 1 & 1 \\
\hline & Female & 2 & 0 & 0 & 0 & 0 & 0 \\
\hline D & Male & 9 & 6 & 4 & 0 & 0 & 1 \\
\hline & Female & 2 & 1 & 1 & 0 & 0 & 0 \\
\hline E & Male & 8 & 4 & 2 & 0 & 1 & 1 \\
\hline & Female & 1 & 1 & 1 & 0 & 0 & 0 \\
\hline F & Male & 3 & 2 & 1 & 0 & 0 & 0 \\
\hline & Female & 3 & 1 & 1 & 0 & 0 & 0 \\
\hline $\begin{array}{l}\text { Total } \\
(\%)\end{array}$ & & 54 & 32 & $19(59.38 \%)$ & 1 & 2 & 6 \\
$(100 \%)$ & $(59.26 \%)$ & & $(3.13 \%)$ & $(6.25 \%)$ & $(18.75 \%)$ \\
\hline
\end{tabular}

Chi-square $=28.125, \quad$ P value $=0.000$ (HHS)

Note: HHS = highly highly significant 


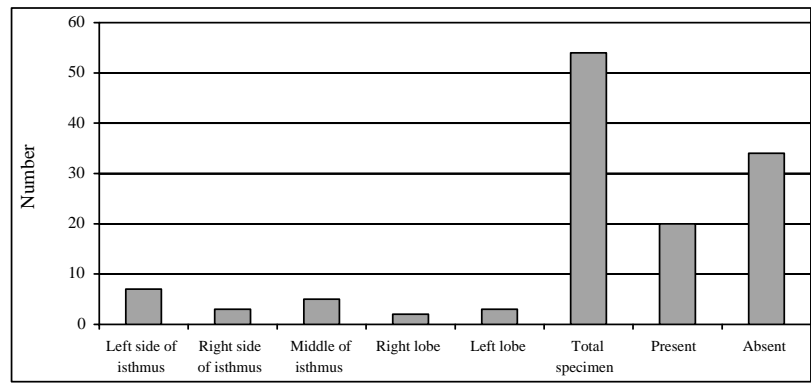

Figure- 1. Bar diagram-showing incidence of pyramidal lobe with its origin and its relation to isthmus.

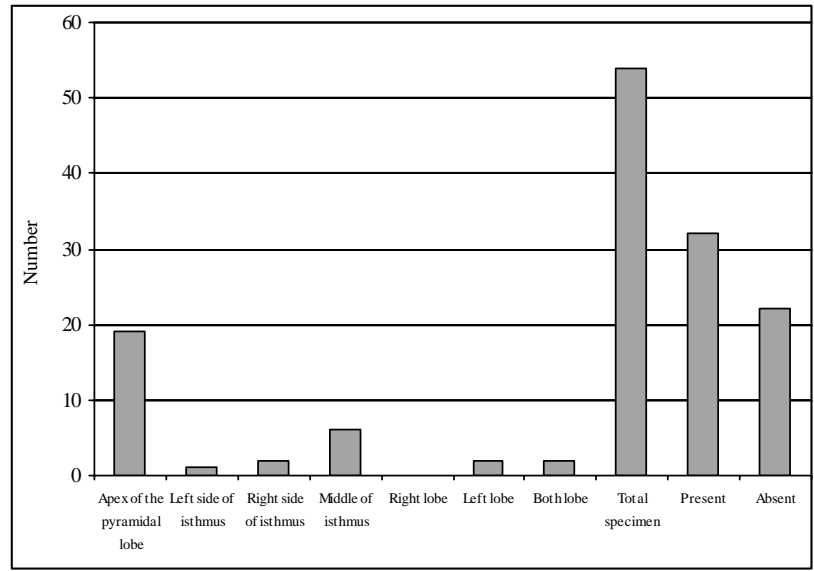

Figure- 2. Bar diagram-showing incidence of levator glandulae thyroideae and its attachment and association with pyramidal lobe.

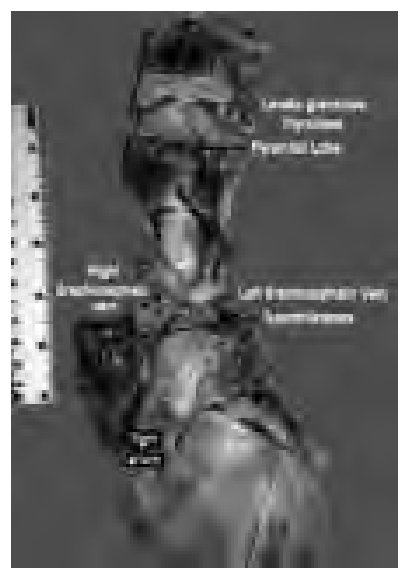

Fig :- 3. Photograph of thyroid gland and great vessels (anterior view), showing levator glandulae thyroideae and pyramidal lobe with their craniocaudal extension and relation.

\section{References:}

1. Hollinshead WH. Text book of anatomy, 3rd edition, Oxford \& IBH publishing co, New Delhi, 1974; 773-76

2.Francis CC. Introduction to human anatomy, 6th edition, The CV Mosby Company, Saint Louis, 1973; 251-53.

3. Sinnatamby CS. Head and neck and spine. In: Last's anatomy: regional and applied, 10th edition, Churchill Livingstone, Edinburgh, 1999; 324-36.

4. Kelly DE, Wood RL, Enders AC. Bailey's textbook of microscopic anatomy,18th edition, Williams and Wilkins, Baltimore, 1984; 794-804.

5. Woodburne RT. Essentials of human anatomy, 5th edition, Oxford University Press, New York, 1973; 153-57.

6. Basmajian JV, Slonecker CE. Grant's method of anatomy, 11th edition, Williams and Wilkins, Baltimore, 1989; 42, 503-4.

7. Kanagasuntheram R, Sivanandasingham P, Krishnamurti A. Anatomy: regional, functional and clinical, PG Publishing, Singapore, 1987; 557-560.

8. Edwards LF, Gaughran GRL. Concise anatomy, 3rd edition, McGraw-Hill Book Companies, New York, 1971; 509-12.

9. Mitchell GAG, Patterson EL. Basic Anatomy, 2nd edition, E \& S Livingstone Ltd, Edinburgh, 1967; 548-50.

10. Patten BM. Human embryology, 3rd edition, McGrawHill Book Company, New York, 1968; 427-42

11. Pansky B. Review of medical embryology, Macmillan Publishing Co., New York, 1982; 136- 37.

12. Moore KL, Persaud TVN. The developing human: Clinically oriented embryology, 6th edition, WB Saunders Company, Philadelphia, 1998; 230-233.

13. Sadler TW. Langman's medical embryology: Head and Neck, 9th edition, Lippincott Williams and Wilkins, Philadelphia, 2004; 363-402.

14. Hansen JT. Embryology and surgical anatomy of the lower neck and superior mediastinum. In: Falk SA. (Editor), Thyroid disease: Endocrinology, surgery, Nuclear Medicine, and Radiotherapy, 2nd edition, Lippincott-Raven Publishers, Philadelphia, 1997; 15-27.

15.Dozois RR, Beahrs OH. Surgical anatomy and technique of thyroid and parathyroid surgery. Surgical Clinics of North America, 1977;57:647-660.

16. Moore KL, Dalley AF II. Clinically oriented Anatomy, 4th edition, Lippincott Williams and Wilkins, Baltimore, 1999; 1030-37.

17.Marshall CF. Variations in the form of the thyroid gland in man. Jour Anat and Phys, 1895; 29: 234-239.

18. April EW. The national medical series for independent study: Clinical Anatomy, 3rd edition, Lippincott Williams and Wilkins, Baltimore, 1997; 573-84. 
19. Hamilton WJ, editor. Textbook of human anatomy, 2nd edition, The Macmillan Press Ltd, London, 1976;488493.

20. DeGroot LJ, Jameson JL. editor. Endocrinology, 4th edition, WB Saunders company, Philadelphia, 2001; 1268-77.

21. Harjeet A, Sahni D, Jit I, Aggarwal AK. Shape, measurments and weight of the thyroid gland in northwest Indians. Surg Radiol Anat, April 2004; 26:915. Available at:

22.Izenstark JL, Forsaith AL, Horwitz NH. The pyramidal lobe in thyroid imaging. Journal of Nuclear Medicine, 1969;10: 519-24.

23. Enayetullah M. Gross and histomorphological study of thyroid and parathyroid glands in Bangladeshi people (M. Phil. thesis), University of Dhaka, 1996; 1-146.

24. Begum M. Gross and histomorphological study of human postmortem thyroid gland in Bangladeshi people (M. Phil. thesis), University of Dhaka. 2004; 1-120.

25. Lehr RP. Musculus levator glandulae thyroideae: An observation. Anat Anz, 1979;146: 494-96. 
lottery. Then out of 17 districts of Dhaka division, Tangail district was selected randomly also by lottery. From 10 rural or outline Upazilas of Tangail district five Upazilas were selected randomly namely Ghatail, Kalihati, Gopalpur, Bashail and Nagorpur. One hundred and five patients attending the emergency departments and 10 doctors were selected purposively from the above mentioned study places. Data were collected through self-constructed questionnaires-one for the patients and another for the doctors. Two draft questionnaires were prepared, designed to meet up the objectives of the study and were pre-tested. Hospital records were reviewed for total number of emergency patients and for the patients who were referred to higher centers. A checklist was use to find out the existing facilities in the Emergency Department and to find out the availability of the service providers in the Emergency Department. Collected data was checked, verified and edited for consistency to reduce error. Finally data was analyzed in computer by using Statistical Package for Social Science ( SPSS ) for window version 11.0

\section{Results:}

The study results reveal that the mean age of patients was 31.28 years. $73 \%$ (77) patients were male and $27 \%$ (28) patients were female. $71 \%$ (75) patients were married and $29 \%$ (30) patients were unmarried. $91 \%$ (96) patients were Muslim and Nine percent patients were Hindu. Most of the patients i.e. $74.3 \%$ (78) live in rural area. Most of the patients i.e. $51.4 \%$ (54) had primary level of education and $6.7 \%$ (7) were illiterate. $22.9 \%$ (24) patients were house wives, $21.9 \%$ (23) were students, $18.1 \%$ (19) were cultivators, $14.3 \%$ (15) were businessmen, $9.5 \%$ (10) were rickshaw pullers and $7.6 \%$ (8) patients were in service. Most of the patients i.e. $55.2 \%$ (58) were in the income group of taka $>5000$. Mean family member of the patients was 5.47.

Out of 5 Upazila Health Complexes ( UHCs ) 2 have toilet facility and remaining 3 do not have. One toilet was found clean and another was found not clean. Among 5 UHCs 3 have functioning $\mathrm{X}$-Ray machines and 2 have nonfunctioning X-Ray machines. 2 UHCs were supplied with X-Ray film and remaining 3 were not. All the 5 UHCs have dark room and Radiographer. (X-Ray facilities for the Emergency Department in UHCs are available only in the morning shift.) All the 5 UHCs have facilities of Blood for Malarial Parasite ( MP ), Urine for Albumin and Sugar for the Emergency Department only in the morning shift.

Table I : General facilities in the Emergency Department (5 Upazila Health Complexes)

\begin{tabular}{|l|c|c|}
\hline Facility & Present & Absent \\
\hline Sign posting and display & 3 & 2 \\
\hline Safe drinking water supply & 5 & 0 \\
\hline Patient trolley or stretcher & 5 & 0 \\
\hline Emergency trolley (with minor surgical set) & 1 & 4 \\
\hline Screen and stand & 2 & 3 \\
\hline IV infusion stand and set & 5 & 0 \\
\hline
\end{tabular}

Table II: Facilities in the Emergency Department with their condition (Total 10 visits)

\begin{tabular}{|l|c|c|c|c|}
\hline Facility & Present & Functioning & $\begin{array}{c}\text { Non- } \\
\text { functioning }\end{array}$ & Absent \\
\hline Register book & 10 & Maintained & 0 & 0 \\
\hline Waste basket & 6 & N.A & N.A & 4 \\
\hline Sputum bowel & 10 & N.A & N.A & 0 \\
\hline $\begin{array}{l}\text { Stethoscope } \\
\text { \& BP Machine }\end{array}$ & 10 & 10 & 0 & 0 \\
\hline Thermometer & 10 & 10 & 0 & 0 \\
\hline Tongue depressor & 10 & 10 & 0 & 0 \\
\hline Auroscope & 4 & 1 & 3 & 6 \\
\hline Tape measure & 1 & 0 & 1 & 9 \\
\hline Weighing machine & 3 & 2 & 1 & 7 \\
\hline Height scale & 3 & 2 & 1 & 7 \\
\hline Torch light & 10 & 9 & 1 & 0 \\
\hline Oxygen cylinder & 2 & 2 & 0 & 8 \\
\hline $\begin{array}{l}\text { Emergency generator } \\
\text { (Alternate power supply) }\end{array}$ & 10 & 6 & 4 & 0 \\
\hline Suction machine & 2 & 2 & 0 & 8 \\
\hline Suturing materials & 9 & N.A & N.A & 1 \\
\hline Canulas & 1 & N.A & N.A & 9 \\
\hline $\begin{array}{l}\text { Disposable syringe } \\
\text { \& needle }\end{array}$ & 9 & N.A & N.A & 1 \\
\hline Glove & 10 & N.A & N.A & 0 \\
\hline $\begin{array}{l}\text { Sterile gauze/ } \\
\text { Micropore/Plaster }\end{array}$ & 10 & N.A & N.A & 0 \\
\hline Stomach tube & N.A & N.A & 0 \\
\hline Nesogastic tube & 10 & N.A & 3 \\
\hline
\end{tabular}

During all the visits Inj. Diclofenac and Inj. Lignocaine $2 \%$ were found present. Tab. Paracetamol, Inj. Hysomide, Inj. Dexamethasone, Inj. Atropine were found in most of the visits. Drugs like Inj. Magnesium Sulphate, Inj. Hydrocortisone, Inj. Pathedine, Inj. Aminophylline, Inj. Gardenal Sodium, Inj. Antihistamin, Inj. Amoxycilin, Lignocaine jelly, Tab. Tri-nitoglycerine and ORS were not present in any visit.

Out of 10 visits by the researcher doctors were found present in 5 visits and absent in 5 visits. Medical Assistant ( MA ) / Nurse / pharmacist and ward boy / Aya were found present in all visits. Sweeper was found present only in 1 visit and absent in 9 visits. Most of the patients i.e. $61.9 \%$ (65) reached the Emergency Department ( ED ) by walking. 37.1 (39) patients reached the ED with the help of relatives and only $1 \%$ (1) patient reached by stretcher.

9.5\% (10) patients needed urgent investigation and 30\% (3) of them got it and 70\% (7) did not get it (due to lack of 
facilities of required investigation in the ED in that shift). $59 \%$ (62) patients were discharged after treatment, 33.3\% (35) were admitted to IPD and $6.7 \%$ (7) were referred to higher centers. Only one (1) patient were not received by the doctor (cool case advised to come to Out Patient Department / OPD on the next day).

Table III : Presence of doctor and Medical Assistant ( MA )/ Nurse/ Pharmacist in the Emergency Department immediately as stated by the patients

\begin{tabular}{|l|c|c|c|c|}
\hline Type of Employ & $\begin{array}{l}\text { Found } \\
\text { present }\end{array}$ & $\begin{array}{c}\text { Found Percent of Percent of } \\
\text { Absent } \\
\text { found } \\
\text { present }\end{array}$ & $\begin{array}{c}\text { found } \\
\text { absent }\end{array}$ \\
\hline Doctor & 26 & 79 & 24.8 & 75.2 \\
\hline MA/Nurse/pharmacist & 99 & 6 & 94.3 & 5.7 \\
\hline
\end{tabular}

Table IV : Waiting time of the patients for receiving Health care in the Emergency Department

\begin{tabular}{|l|c|c|}
\hline Waiting time & Frequency & Percent \\
\hline Up to 2 minutes & 61 & 58.1 \\
\hline 2-4 minutes & 23 & 21.9 \\
\hline 4-6 minutes & 13 & 12.4 \\
\hline 6- 10 minutes & 7 & 6.7 \\
\hline$>10$ minutes & 1 & 1.0 \\
\hline Total & 105 & 100.0 \\
\hline
\end{tabular}

Table V : Referral rate of the patients in the Emergency Department

\begin{tabular}{|l|c|c|c|}
\hline Study place & Total patients & Referred patients & Referral rate \\
\hline Ghatail & 42 & 4 & $9.5 \%$ \\
\hline Kalihati & 34 & 2 & $6.8 \%$ \\
\hline Gopalpur & 22 & 1 & $4.5 \%$ \\
\hline Bashail & 24 & 1 & $4.1 \%$ \\
\hline Nagorpur & 21 & 2 & $9.5 \%$ \\
\hline Total & 143 & 10 & $7.0 \%$ \\
\hline
\end{tabular}

Out of 12 patients using toilet in the ED $58.4 \%$ (7) were poorly satisfied, $33.3 \%$ (4) were satisfied and $8.3 \%$ (1) patients was not satisfied regarding cleanliness of toilet in the ED. 55\% (58) patients did not received doctor's service and $45 \%$ (47) patients received doctor's service. Most of the patients i.e. $91.4 \%$ (96) were satisfied with overall management of the ED.

$80 \%$ (8) doctors stated patients' attitude as good but sometimes not satisfactory. $90 \%$ (9) doctors stated attendants' attitude as good but sometimes not satisfactory. $90 \%$ (9) doctors stated that violence was shown by the patients/ attendants occasionally. $80 \%$ (8) doctors faced problems occasionally in providing health care service properly. $55.6 \%$ (5) doctors faced problems to provide health care service from attendants, $33.3 \%$ (3) from both authority and attendants and $11.1 \%$ (1) from authority only.

Out of ten (10), seven (7) doctors did not think the ED well staffed. Shortage of staff mentioned was trained EMO, MA, Nurse, Ward boy and Sweeper. Out of ten (10), nine (9) doctors were not satisfied with their job. Causes of job dissatisfaction mentioned by them were unsuitable working environment, overload of work, lack of necessary drugs and logistics, unsatisfactory salary, no promotion, lack of accommodation, political mal-influence, unstable and flexible roster duty, unsatisfactory behaviour of the authority.

\section{Discussion:}

The findings of age are consistent with the study of Kaiser $\mathrm{FR}^{7}$, Bhuiya M Faruk ${ }^{8}$ and Dr. Begum Aleya, done on of the Emergency Department of Dhaka Medical College Hospital, who found majority of the patients $(65 \%)$ were of young age group 9 . Male persons are more as they work outside more and they are more prone to accident and other acute conductions. Majority of the patients $(91.43 \%)$ were Muslim which was consistent with the percentage of Muslims in Bangladesh.

From the checklist prepared as per Standard Operating Procedure ( SOP ) it was found that among 5 UHCs, three (3) UHCs have sign posting and display and remaining two (2) have not. All the 5 UHCs have safe drinking water supply, patient trolley or stretcher and IV infusion stand and set. 4 UHCs do not have emergency trolley (with minor surgical set) and 3 UHCs do not have screen and stand in the ED (Table-I \& II). As per Standard Operating Procedure certain drugs must be present in the ED of UHCs. But most of those drugs were not found in the EDs.

It was seen that $75.2 \%$ (79) patients found doctor absent in the ED immediately. $94.3 \%$ (99) patients found MA/Nurse/Pharmacist present in the ED immediately and $5.7 \%$ (6) patients found MA/Nurse/Pharmacist absent in the immediately (Table-III). 61.9\% (65) patients reached the ED by walking and $37.1 \%$ (39) with the help of relatives and only $1 \%$ by stretcher. This indicates the absence of patient trolley in the ED and or lack of hospital staff to pull it.

Regarding waiting time the highest percentage i.e. $58.1 \%$ (61) required waiting time with 2 minutes followed by $21.9 \%$ (23) within 2-4 minutes. Only $1 \%$ patients need waiting time $>10$ minutes (Table-IV). This was much 
satisfactory than the results of the study of Rhaman $\mathrm{H}^{10}$ and Dr. Begum Aleya where she found waiting time 2-4 minutes only in $34.7 \%$ cases $^{9}$. It correlates with the study of Bhuiyan where in $75.2 \%$ cases waiting time was less than 5 minutes ${ }^{8}$. In the workshop on "Health Care Quality Assurance" which was held in August 1995 it was suggested that waiting time should be within 10 minutes in serious cases and 20 minutes in less serious cases ${ }^{11}$.

Out of 105 patients $59.0 \%$ (62) were discharged after treatment, $33.3 \%$ (35) were admitted to the IPD and $6.7 \%$ (7) were referred to the higher centers. These findings show dissimilarity with the study of Dr. Mazid Abdul in Holly Family Red Crescent Medical College Hospital, Dhaka where $24.55 \%$ were discharged after treatment, $>4.5 \%$ were admitted and one patients was referred to higher center ${ }^{2}$.

One hundred and five patients were asked for providing suggestions for better management of the ED. Among them 43 provided suggestions and remaining 62 did not. Most patients desired supply of medicine required for their treatment. Some patients suggested ensuring $\mathrm{O}_{2}$ supply, $\mathrm{X}$ Ray facilities and other modern facilities for emergency patients. Some patients expected the presence of doctor in the ED always. Some patients gave emphasis on cleanliness of the ED.

Ten doctors were asked about equipment status of the ED. Among them 9 doctors considered the ED not well equipped. Deficiency / shortage mentioned were $\mathrm{O}_{2}$ cylinder, Sucker Machine, Nebulizer machine, Mini OT with necessary instruments, Emergency light, Weight Machine, AC, Trolley, Autoclave, Auroscope, Gloves, Adequate supply of medicine, Attached toilet, Attached doctor's room etc.

Referral rate of patients in the ED for Ghatail UHC was $9.5 \%$, for Kalihati UHC $6.8 \%$, for Gopalpur UHC $4.5 \%$, for Bashail UHC $4.1 \%$ and for Nagorpur UHC it was $9.5 \%$. The average referral rate was $7.0 \%$ (Table-V). No previous data was available to compare these findings.

From the study results it was found that emergency departments of Upazila Health Complexes are not so clean, not well equipped and not well staffed. Though the waiting time was satisfactory, doctor presence was poor. Most of the patients received services from either Medical Assistant or Nurse or Pharmacist. Diagnostic facilities play a vital part in the management of patients. Diagnostic facilities for the patients of the Emergency Departments in Upazila Health Complexes are available to some extent only in the morning shift. Life saving drugs is not available or inadequately available in the Emergency Departments. The results of the study indicate further study in this field. The findings of the study may be useful in the improvement of the management status of the emergency services in the Upazila Health Complexes.

\section{Acknowledgement:}

I am grateful to Prof. Dr. Rowshan Ara Begum, Professor and head, and to my guide Dr. Zahidur Rahman, Assistant Professor of the department of Public Health and Hospital Administration, NIPSOM for their inspiring guidance, valuable suggestions, constant supervision and co-operation.

I would like to thank The Then Upazila Health And Family Planning Officers, RMOs Medical Officers, Medical Assistants, Nurses, Pharmacists and other staff of Upazila Health Complexes of Ghatail, Khalihati, Gopalpur, Bashail and Nagorpur for their sincere co-operation and help during the period of my data collection.

\section{Bibliography:}

1. DGHS, Standards for District Hospitals, Development of Health Care Quality Assurance Project, 1997:1,2.

2. Dr. Mazid Abdul, Management of Emergency department in a selected non-government Medical College Hospital, Dhaka, 2003:2,9-11.

3. DGHS, Primary Health Care Related Policy And Strategy, 2000:1-8.

4. DGHS, United Management Information System (UMIS), Health and Population Statistical Report 19992000:10.

5. Davies R L Lewellyn and Macaulay H.M.C, Hospital Planning and administration; 1st Edition, 1995: 121124.

6. Prof (Dr.) Salahuddin A. K. M. Hospital Management, 2nd edition: 13-14.

7. Kaiser FR, Willingness to pay more fees on OPD Patients of Hospital for better services, Dhaka, 1996:109

8. Bhuiya M Faruque, Study on Selected Patients (Burn) in ED of DMCH, 1998:2.

9. Begum Aleya, Study on waiting time of the patients attending in the ED in a selected tertiary level hospital, 1999:40.

10. Rahman H. Study on waiting time in Diabetic patient attending BIRDEM, Dhaka 1987:78.

11. Rahman G.R.M. Moksedur MPH (H.M.): Quality care of the inpatient department Medical ward of District Hospital 1996-97;1:32-34. 